\title{
Tracking the Sputnik Economy
}

\section{EDWARD B. BARBIER}

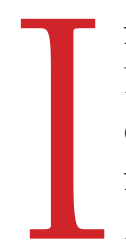

n his 2011 State of the Union Address, President Obama stressed the urgency of "winning the future" by comparing the current economic situation to 50 years ago, "when the Soviets beat us into space with the launch of a satellite called Sputnik." Spurred by the 1960s space race, the United States "unleashed a wave of innovation that created new industries and millions of new jobs."

According to the President, "this is our generation's Sputnik moment" requiring renewed investment in the economy: from developing clean energy to advancing $R \& D$ to rebuilding infrastructure to expanding educational

Edward B. Barbier is the John S. Bugas Professor of Economics at the University of Wyoming and specializes in the economics of natural resources and development.

๑ Berkeley Electronic Press Brought to you by | University opportunities. "All these investments-in innovation, education and infrastructure-will make America a better place to do business and create jobs."

Obama's vision is laudable. But just as the orbits of satellites have to be tracked properly in space, we need better economic indicators to judge the effectiveness of such an investment strategy.

Since 1991, the U.S. Bureau of Economic Analysis has used real per capita Gross Domestic Product (GDP), the market value of all final goods and services produced within the United States, as the basis for measuring growth in the economy. The problem with GDP as an economic indicator, however, is that it does not reflect changes in the capital stock underlying the production of goods and services. Since the purpose of new investment is to increase the net quantity and quality of the economy's total capital stock, adjusting GDP for net new investment (after depreciation) would measure more accurately whether new additions to capital are occurring.

\section{AN ALTERNATIVE INDICATOR}

The idea of deducting any real capital deI preciation from GDP to obtain a "Net" Domestic Product (NDP) measure is not new. As Partha Dasgupta has noted, Erik Lundahl provided the justification in the 1930s by suggesting that an economy's income should exceed current consumption, including any consumption of existing capital, to prevent comprehensive wealth from declining. However, the total stock of economic assets should be much broader than conventional reproducible (or fixed) assets, such as roads, buildings, 
machinery and factories. Investments in human capital, such as education and skills training, are also essential to sustaining development. Similarly, an economy's endowment of natural resources is an important form of "natural wealth." Thus, a better indicator of an economy's progress would be an expanded measure of NDP that is "adjusted" for real depreciation in reproducible and natural capital, as well as any net additions to human capital, such as through real education expenditures in the economy.

An approximate estimate of adjusted Net Domestic Product (ANDP) per capita can easily be constructed from the World Bank's World Development Indicators. The WDI includes consumption of fixed capital, total education expenditures, and depreciation of some natural resources, such as fossil fuels, minerals and timber from 1970 to 2008 for many economies, including the United States.

Figure 1 compares trends in real GDP and ANDP per capita for the United States from 1970 to 2008. Although the two measures generally follow the same long-run trend, ANDP per capita is consistently lower than GDP per capita. In addition, the gap between the two
Figure 1

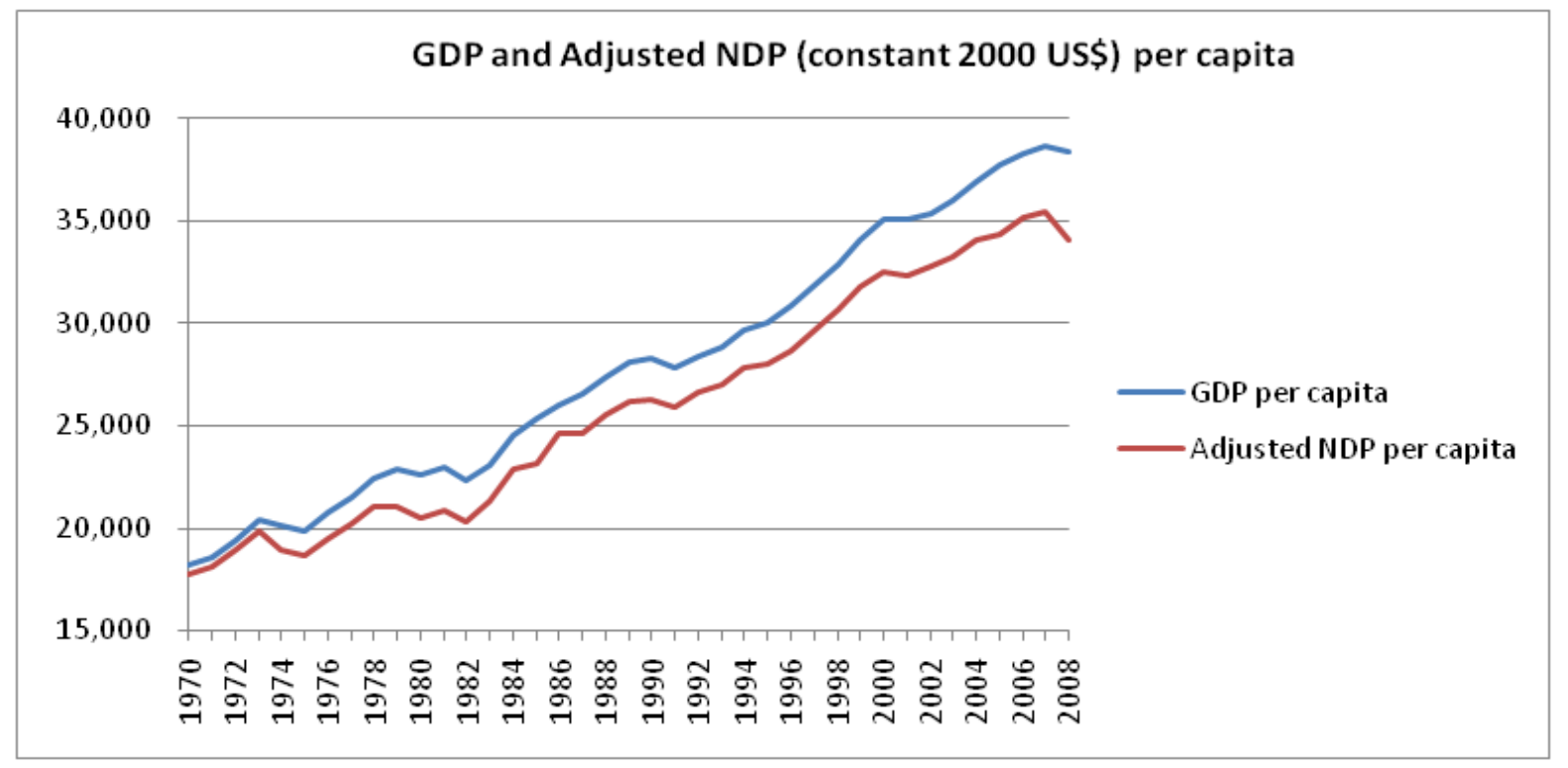

indicators has been widening. In 1970, real GDP per capita was $\$ 18,229$, and ANDP per capita was $\$ 17,786$, but by 1990 , GDP per capita had risen to $\$ 28,299$ whereas ANDP per capita was $\$ 26,288$. By the 2000s, the gap had increased further; by 2007, real GDP per capita reached $\$ 38,701$, and ANDP per capita was only $\$ 35,497$. Both indicators fell in 2008, signaling the start of the Great Recession. However, the decline in ANDP per capita of 4.0 percent over 2007-8 was significantly greater than the 0.9 percent fall in GDP per capita.

Table 1 indicates that, from 1970 to 2008, the average annual growth rate in real GDP per capita (2.0 percent) and real ANDP per capita (1.9 percent) were similar. Fixed capital 
Table 1

Average annual growth rate per capita (constant 2000 US\$)

\begin{tabular}{lccccc}
\hline \hline & GDP & ANDP & $\begin{array}{c}\text { Consumption of } \\
\text { fixed capital }\end{array}$ & $\begin{array}{c}\text { Education } \\
\text { expenditures }\end{array}$ & $\begin{array}{c}\text { Energy and } \\
\text { mineral depeletion }\end{array}$ \\
\hline $1970-79$ & $2.4 \%$ & $1.7 \%$ & $4.8 \%$ & $1.5 \%$ & $20.3 \%$ \\
$1980-89$ & $2.7 \%$ & $3.0 \%$ & $1.7 \%$ & $-1.9 \%$ & $-24.8 \%$ \\
$1990-99$ & $2.2 \%$ & $2.2 \%$ & $2.2 \%$ & $1.4 \%$ & $-10.7 \%$ \\
$2000-08$ & $1.7 \%$ & $1.1 \%$ & $2.6 \%$ & $1.3 \%$ & $16.9 \%$ \\
$1970-2008$ & $2.0 \%$ & $1.9 \%$ & $2.6 \%$ & $0.5 \%$ & $-1.5 \%$ \\
\hline
\end{tabular}

depreciation per capita grew 2.6 percent annually, but energy and mineral depletion per person fell by 1.5 percent annually. Educational expenditures per capita grew modestly each year by 0.5 percent.

However, for each decade, annual average growth rates vary significantly. Of particular concern is that the pattern of growth of the 1970 s is being replicated in the 2000s. In the 1970s, per capita reproducible and natural capital depreciation rose substantially each year (4.8 and 20.3 percent, respectively), whereas per capita educational expenditures grew only modestly (1.5 percent). As a result, average annual growth in ANDP per capita lagged behind growth in GDP. Although ener- gy and mineral depletion fell over subsequent decades, from 2000 to 2008 natural resource depreciation per capita grew 16.9 percent annually. The average annual growth rate in fixed capital consumption was also higher (2.6 percent), whereas the annual average growth in educational expenditures per capita was lower ( 1.3 percent). Once again, growth in ANDP per capita (1.1 percent) lagged behind growth in GDP per capita (1.4 percent).

\section{POLICY IMPLICATIONS}

These comparisons of GDP and ANDP per capita for the United States are revealing in several respects. First, ANDP is a better indicator of whether or not current increases in an economy's real income from domestic production is leading to net additions to capital. Second, the U.S. economy remains dependent on depreciating its mineral and energy assets. Reducing this dependence through clean energy investments is not just an urgent priority; it may be an economic necessity Finally, President Obama is right to be concerned that overall net investment growth is starting to lag in the U.S. economy, and has been severely affected by the Great Recession. If trends since 2000 are not reversed soon, then "winning the future" may no longer be an option for the U.S. economy.

Letters commenting on this piece or others may be submitted at submit.cgi? context=ev.

\section{REFERENCES AND FURTHER READING}

Arrow, Kenneth J., Partha Dasgupta, Lawrence Goulder, Gretchen Daily, Paul Ehrlich, Geoffrey M. Heal, Simon Levin, Karl-Göran Mäler, Stephen Schneider, David A. Starrett and Brian Walker (2004) "Are We Consuming Too Much?"

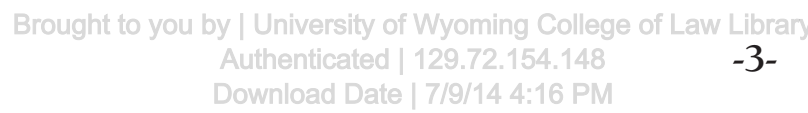


Journal of Economic Perspectives, 18(1):147172. Available at http://www.econ.cam.ac.uk/ faculty/dasgupta/toomuch.pdf.

Barbier, Edward B (2005) Natural Resources and Economic Development. Cambridge University Press, Cambridge and New York.

Dasgupta, Partha (2009) "The Welfare Economic Theory of Green National Accounts," Environmental and Resource Economics, 42(1):338. Available at http://ideas.repec.org/a/kap/enreec/v42y2009ilp3-38.html.

Hamilton, Kirk and Michael Clemens (1999) "Genuine Savings Rates in Developing Countries," World Bank Economic Review, 13(2):333356. Available at http://wber.oxfordjournals.org/ content/13/2/333.abstract. 3a18 3ay $3 a 2004$ 3ai 3a3 3ap 3al47-172.htm.

World Bank (2010) "World Development Indicators 2010." Available at http://data.worldbank. org/data-catalog/world-development-indicators. 